Published with Open Access at Journal BiNET

Vol. 09, Issue 01: 782-791

Journal of Bioscience and Agriculture Research

Home page: www.journalbinet.com/jbar-journal.html

\title{
Performance of eight tomato mutants in winter season
}

\author{
S. Ghosh ${ }^{a}$, M. H. Khan ${ }^{a}$, K. C. Saha ${ }^{a}$, M. G. Azam ${ }^{a}$ and M. H. R. Pramanik ${ }^{b}$ \\ aBangladesh Agriculture Research Institute (BARI), Rangpur \\ bDept. of Crop Botany, Bangladesh Agricultural University, Mymensingh, Bangladesh
}

凶 fssuprio@gmail.com (Ghosh, S.), $\$$ +88-017-12876095, Published: 25 April 2016

\begin{abstract}
Eight tomato mutants (TM-113, TM-127, TM-128, TM-131, TM-132, TM-133, TM-134 and TM-160) along with two reference varieties (Binatomato-4, Binatomato-5) were evaluated based on their morpho-physiological features, reproductive characters, yield attributes and fruit yield at the experimental farm of Bangladesh Institute of Nuclear Agriculture (BINA). The experiment was laid out in a randomized complete block design with three replications. The mutants differed significantly from their morphological features (plant height, branch and leaf number, leaf area, etc.), growth characters (root weight and total dry mass plant ${ }^{-1}$, absolute and relative growth rate), biochemical parameters (chlorophyll, total sugar, nitrate reductase and vitamin-C contents), reproductive behaviour (number of effective and non-effective flower cluster plant ${ }^{-1}$, number of flowers plant ${ }^{-1}$ and reproductive efficiency), yield attributes and fruit yield. Superior performance in leaf area, total dry mass production, absolute growth rate, nitrate reductase activity and total sugar content in leaves, number of flower cluster and flowers plant ${ }^{-1}$ which resulted higher number of fruits plant ${ }^{-1}$. Chlorophyll content and reproductive efficiency had little or no significant contribution to fruit yield. Fruit yield had highly significant positive correlation with leaf area, total dry mass, absolute growth rate, number of flower clusters and fruits plant ${ }^{-1}$, while fruit size had significant negative association with fruit number. This result indicates that the improvement of fruit number plant ${ }^{-1}$ could be achieved by selecting increased number of effective flower cluster plant ${ }^{-1}$. The mutant, TM-133 maintained superiority to the other mutants for yield related traits and produced highest fruit yield (95.1 $\left.\mathrm{tha}^{-1}\right)$ and thus, it may be treated as a promising mutant to release as variety.
\end{abstract}

Key Words: Tomato, Mutant, Binatomato, Yield, Genotype and Variety

\footnotetext{
Cite article: Ghosh, S., Khan, M. H., Saha, K. C., Azam, M. G. \& Pramanik, M. H. R. (2016). Performance of eight tomato mutants in winter season. Journal of Bioscience and Agriculture Research, 09(01), 782-791.
}

Article distributed under terms of a Creative Common Attribution 4.0 International License.

\section{Introduction}

Tomato (Lycopersicon esculentum Mill.), is one of the foremost vital widely held and alimentary vegetable crop in Bangladesh moreover as within the world. It's grown up throughout the country for its ability to wide selection of soil and climate. It ranks next to potato and sweet potato in respect of production within the world (FAO, 2007), however in Bangladesh, it ranks $2^{\text {nd }}$ that is next to potato (BBS, 2009) and high the list of canned vegetables (Ahmed, 2008). Its food price is extremely made as 
a result of higher contents of $\mathrm{A}, \mathrm{B}$ and $\mathrm{C}$ together with metal, minerals, carotene and iron (Bose \& Som, 1990). It's a wholesome and delicious vegetable employed in dish, soups and processed into stable product like tomato ketchup, sauce, pickles paste, condiment and juice. They are extensively employed in the canning trade (Hossain et al., 2004). The yield of tomato in Bangladesh is not satisfactory compared to other tomato growing countries (FAO, 2007). Average yield of tomato in Bangladesh is $16.72 \mathrm{t} \mathrm{ha}^{-1}$ (BBS, 2009) which is quite low compared to the tomato growing countries like Japan (62.99 t ha-1), USA (66.57 t ha-1), Turkey (42.50 t ha-1), Brazil (54.55 t ha-1) and Italy (53.22 t ha-1) (FAO, 2007). To meet nutritionary demand of population, it's vital to extend the yield of tomato per unit space of land. Increase of production depends upon several factors like use of improve varieties and correct management practices. So, the techniques like typical breeding strategies, nuclear technique or genetic engineering are often used for developing high yielding tomato varieties with smart quality adaptive to grow beneath the prevailing environmental conditions (Ashrafuzzaman et al., 2010). Varietal improvement of tomato is essentially needed to increase fruit yield by creating variability in the available germplasms followed by appropriate selection procedures. The induced mutation breeding is an effective technique for creating substantial genetic variability in plant species. Somaclonal variation in crop can be achieved through physical mutagens particularly gamma radiation (Begum, 2005). This technique has been successfully utilized by Bangladesh Institute of Nuclear Agriculture (BINA) and many other research institutes in the world. The mutation breeding can play an efficient role in developing an ideal plant type having superior physiological performance as well as high yield (Dutta, 2001). To increase productivity in tomato, it is necessary to create variability and select desirable type with stable yield. However, biochemical properties are related to yield of tomato plant (Dutta, 2004). The higher chlorophyll contents, nitrate reductase activity and total sugar levels are helpful in increasing fruit yield in tomato (Dutta, 2004). Component characters for yield are interdependent to each other while one character may express at the expense of other (Sharma et al., 2006; Hidayatullah et al., 2008). The importance of correlation in any breeding programme is well documented for various crop species as it provides a basis for effective selection. Correlation index acts as a guide to the reliability of phenotypic and genotype values and determines success in crop improvement (Singh et al., 2009). Under these circumstances, the scientists of crop physiology division of BINA have developed several promising mutants of tomato with high yield potentials. These mutants need to be assessed for their morphological and physiological maneuvering that takes place compared to the existing tomato cultivars. Thus, the present research work was designed to evaluate the performances of eight elite tomato mutants along with two reference varieties based on their morpho-physiological features, reproductive characters, yield attributes and fruit yield.

\section{Materials and Methods}

The experiment was carried out at laboratory and experimental field of Bangladesh Institute of Nuclear Agriculture (BINA), Mymensingh during October 2009 to March 2010. The experiment consisted of eight tomato mutants each representing a treatment along with two reference varieties. The mutants were TM-113, TM-127, TM-128, TM-131, TM-132, TM-133, TM-134, TM-160 and the reference varieties were Binatomato-4 and Binatomato-5. The experiment was laid out in a Randomized Complete Block Design (RCBD) with three replications. The unit plot size was $3.0 \mathrm{~m} \times 4.0$ $\mathrm{m}$. Tomato seedlings were raised in seedbed. The seeds of each genotype were sown in the seed bed on 20 October, 2009. The seed beds were prepared in iron sheet tray $(50 \mathrm{~cm} \mathrm{x} 60 \mathrm{~cm})$. After sowing, the seeds were covered with light soil. 25-day old seedlings were transplanted in the experimental plot on 15 November, 2009. First harvest of ripen tomato started at 80 DAT. At initial ripening stage, ripen tomato was harvested at 5-day interval and after a few days, ripen tomato was harvested at 2-day interval. All the harvests came to end in March 2010. The data were collected on morphological parameters- plant height $(\mathrm{cm})$, number of branches plant ${ }^{-1}$, number of leaves plant ${ }^{-1}$ and leaf area plant $^{-1}\left(\mathrm{~cm}^{2}\right)$; growth parameters- total dry matter plant ${ }^{-1}$, root weight plant ${ }^{-1}$, absolute growth rate and relative growth rate; biochemical parameters- chlorophyll estimation, nitrate reductase (NRase) activity, determination of total sugar and vitamin $C$ content in fruit; reproductive characters- number of effective flower cluster plant ${ }^{-1}$, number of non-effective flower cluster plant ${ }^{-1}$, number of flowers plant $^{-1}$ and reproductive efficiency; yield and yield contributing characters- number of fruits plant ${ }^{-1}$, single fruit weight, fruit yield plant ${ }^{-1}$, fruit yield $\left(\mathrm{t} \mathrm{ha} \mathrm{a}^{-1}\right)$. 


\section{The following formulas were used for calculating different parameters:}

The growth analysis like AGR and RGR was carried out following the formulae of Hunt (1978).

Absolute growth rate $(\mathrm{AGR})=\frac{\mathrm{W} 2-\mathrm{W} 1}{\mathrm{~T} 2-\mathrm{T} 1} \mathrm{~g}$ plant $^{-1}$ day-1 $^{-1}$

Relative growth rate $(\mathrm{RGR})=\frac{\ln \mathrm{W} 2-\ln \mathrm{W} 1}{\mathrm{~T} 2-\mathrm{T} 1} \mathrm{~g} \mathrm{~g}^{-1} \mathrm{day}^{-1}$

Where,

$\mathrm{W}_{2}$ and $\mathrm{W}_{1}$ are the $\mathrm{DM}$ at time $\mathrm{T}_{2}$ and $\mathrm{T}_{1}$, respectively.

Chlorophyll was estimated following the procedure of Yoshida et al. (1976). Chlorophyll content was estimated as follows:

Total chlorophyll $\left(\mathrm{mg} \mathrm{g}^{-1} \mathrm{fw}\right)=\left[20.2 \times \mathrm{A}_{645}-8.02 \times \mathrm{A}_{663}\right] \times 0.2$

NRase was estimated following the procedure of Stewart and Orebanjo (1979). NRase measurement was estimated as follows:

NRase $=$ Correction factor $\mathrm{x}$ dilution factor $\mathrm{x}$ optical density $\mathrm{x}$ incubating time

Total sugar was determined by the phenol- $\mathrm{H}_{2} \mathrm{SO}_{4}$ method of Dubois et al. (1956). Total sugar measurement was estimated as follows:

Total sugar $\left(\mathrm{mg} \mathrm{g}^{-1} \mathrm{fw}\right)=$ Correction factor $\mathrm{x}$ dilution factor $\mathrm{x}$ optical density .

Vit-C was determined by the meta phosphoric acid (AOAC, 1980). Vitamin C content was calculated by using the following formula.

$\begin{array}{ll}\text { Vitamin C content }=\frac{T \times D x V 1}{V 2 x W} \times 100(m g / 100 g) & \begin{array}{l}\text { Where, } \\ \text { T=Titre, D=Dye factor, } \mathrm{V}_{1}=\text { Volume made up, } \mathrm{V}_{2}=\text { Volume of extract } \\ \text { taken for estimation, and W= Weight of sample }\end{array}\end{array}$

Reproductive efficiency $(\mathrm{RE})=\frac{\text { total no of fruits } / \text { plant }}{\text { total no of open flower } / \text { plant }} \times 100$

Statistical analysis The collected data were analyzed statistically following the analysis of variance (ANOVA) technique and the mean differences were adjudged by Duncan's Multiple Range Test (DMRT) using the statistical computer package program, MSTAT-C (Russell, 1986). The simple correlation coefficient among the quantitative characters was estimated by using the statistical computer package program, MSTAT-C (Russell, 1986).

\section{Results and Discussion}

\section{Morphological parameters}

The variation in plant height among the mutants/varieties differed significantly (Table 01). The tallest plant was recorded in TM-113 $(110.2 \mathrm{~cm})$ followed by TM-128 $(104.0 \mathrm{~cm})$. In contrast, the shorter plant was recorded in TM-132 $(68.3 \mathrm{~cm})$ and TM-160 $(68.7 \mathrm{~cm})$ with same statistical rank. These results were in agreement with the result of Sharma et al. (2006) who stated that plant height differed significantly among the studied genotypes in tomato. There was a significant variation among the mutants/varieties in respect of branch number plant ${ }^{-1}$ (Table 01). The number of branches plant ${ }^{-1}$ was maximum in Binatomato-5 (6.89) and TM-128 (6.44). On the other hand, the minimum number of branches plant ${ }^{-1}$ was recorded in TM-160 (4.00). Genotypic variability in branching was also observed by many workers in tomato (Sandri et al., 2003; Asati et al., 2008; Hidayatullah et al., 2008; Prashanth et al., 2008). 
Table 01. Morphological characters of tomato mutants and varieties in this study

\begin{tabular}{lllllll}
\hline Mutants/ & $\begin{array}{l}\text { Plant height } \\
\text { varieties }\end{array}$ & \multicolumn{2}{l}{$\begin{array}{l}\text { Branches } \\
\text { (cm) }\end{array}$} & \multicolumn{2}{l}{ Leaves/plant at } & \multicolumn{2}{c}{ Leaf area/ plant $\left(\mathrm{cm}^{2}\right)$ at } \\
\cline { 4 - 7 } & $70.5 \mathrm{e}$ & $4.89 \mathrm{ef}$ & $21.2 \mathrm{~cd}$ & $45.1 \mathrm{bc}$ & $897 \mathrm{f}$ & $1867 \mathrm{~g}$ \\
\hline Binatomato-4 & $99.0 \mathrm{bc}$ & $6.89 \mathrm{a}$ & $25.3 \mathrm{~b}$ & $53.3 \mathrm{a}$ & $1589 \mathrm{~d}$ & $3320 \mathrm{ef}$ \\
Binatomato-5 & $110.2 \mathrm{a}$ & $6.11 \mathrm{bc}$ & $20.0 \mathrm{de}$ & $42.4 \mathrm{c}$ & $2525 \mathrm{c}$ & $5565 \mathrm{~cd}$ \\
TM-113 & $86.6 \mathrm{~d}$ & $5.29 \mathrm{de}$ & $22.1 \mathrm{~cd}$ & $43.3 \mathrm{c}$ & $2669 \mathrm{c}$ & $5230 \mathrm{~d}$ \\
TM-127 & $104.0 \mathrm{~b}$ & $6.44 \mathrm{ab}$ & $28.5 \mathrm{a}$ & $49.6 \mathrm{ab}$ & $4541 \mathrm{a}$ & $7937 \mathrm{a}$ \\
TM-128 & $83.1 \mathrm{~d}$ & $4.67 \mathrm{f}$ & $20.2 \mathrm{de}$ & $36.1 \mathrm{~d}$ & $3360 \mathrm{~b}$ & $6065 \mathrm{bc}$ \\
TM-131 & $68.3 \mathrm{e}$ & $4.78 \mathrm{ef}$ & $18.4 \mathrm{e}$ & $33.8 \mathrm{de}$ & $1237 \mathrm{e}$ & $2091 \mathrm{~g}$ \\
TM-132 & $93.9 \mathrm{c}$ & $5.78 \mathrm{~cd}$ & $27.8 \mathrm{a}$ & $49.7 \mathrm{ab}$ & $3480 \mathrm{~b}$ & $6206 \mathrm{~b}$ \\
TM-133 & $83.1 \mathrm{~d}$ & $5.00 \mathrm{ef}$ & $23.0 \mathrm{bc}$ & $36.0 \mathrm{~d}$ & $2377 \mathrm{c}$ & $3721 \mathrm{e}$ \\
TM-134 & $68.7 \mathrm{e}$ & $4.00 \mathrm{~g}$ & $18.2 \mathrm{e}$ & $30.2 \mathrm{e}$ & $1685 \mathrm{~d}$ & $2783 \mathrm{f}$ \\
TM-160 & 5.62 & 0.55 & 2.50 & 4.82 & 310.2 & 607.6 \\
\hline$L S D(0.05)$ &
\end{tabular}

In a column figures having same letter $(\mathrm{s})$ do not differ significantly at $\mathrm{P} \leq 0.05$

The mutants TM-128 and TM-133 and variety Binatomato- 5 produced higher number of leaves plant ${ }^{-1}$ at the both growth stages (Table 01). But at $60 \mathrm{DAT}$, the maximum leaves production was recorded in Binatomato-5 (53.3). The mutant TM-160 produced the few leaves plant ${ }^{-1}$ at the both growth stages (18.2 and 30.2 for 40 and 60 DAT, respectively), which was statistically identical to TM-132 (18.4 and 33.8 for 40 and 60 DAT, respectively). This result was in agreement with the result of Singh and Raj (2004) in tomato. The highest leaf area (LA) was recorded in TM-128 (4541 and $7937 \mathrm{~cm}^{2}$ for 40 and 60 DAT, respectively). The lowest LA was recorded in Binatomato-4 (897 and $1867 \mathrm{~cm}^{2}$ for 40 and 60 DAT, respectively). The leaf number of Binatomato- 4 was medium but the LA was the lowest due to smaller size leaflets. The result obtained from the present study is in consistent with result of Heuvelink (1999) in tomato who stated that variation in LA could be attributed to the changes in number of leaves and their expansion.

\section{Growth characters}

Root weight plant ${ }^{-1}$ varied significantly among the mutants/varieties (Table 02). The highest root weight was observed in TM-128 (11.2 $\left.\mathrm{g} \mathrm{plant}^{-1}\right)$ followed by TM-131 (9.37g plant ${ }^{-1}$ ). The lowest root weight was recorded in TM-132 (4.31 glant $\left.^{-1}\right)$ that was not different significantly from TM-160 $(4.49 \mathrm{~g}$ plant $^{-1}$ ) and Binatomato-4 (4.90g plant ${ }^{-1}$ ). Genotypic variability in root weight was also observed by BINA (2008) in tomato.

Table 02. Growth characters of tomato mutants and varieties/cultivars recorded at different growth stages

\begin{tabular}{|c|c|c|c|c|c|}
\hline \multirow{2}{*}{$\begin{array}{l}\text { Mutants/ } \\
\text { varieties }\end{array}$} & \multirow{2}{*}{$\begin{array}{l}\text { Root weight } \\
\text { /plant (g) }\end{array}$} & \multicolumn{2}{|c|}{$\begin{array}{l}\text { Total dry mass } \\
\text { /plant }(\mathrm{g})\end{array}$} & \multirow{2}{*}{$\begin{array}{l}\text { Absolute growth rate } \\
\text { at } 40-60 \text { DAT } \\
\text { (g/plant/day) }\end{array}$} & \multirow{2}{*}{$\begin{array}{l}\text { Relative growth rate } \\
\text { at } 40-60 \text { DAT } \\
\text { (mg/g/day) }\end{array}$} \\
\hline & & $40 \mathrm{DAT}$ & 60 DAT & & \\
\hline Binatomato-4 & $4.90 \mathrm{f}$ & $9.66 \mathrm{~h}$ & $40.0 \mathrm{f}$ & $1.52 \mathrm{ef}$ & $71.1 \mathrm{a}$ \\
\hline Binatomato-5 & $6.18 \mathrm{e}$ & $22.66 \mathrm{~d}$ & $84.9 c$ & $3.11 \mathrm{bc}$ & $66.0 \mathrm{ab}$ \\
\hline TM-113 & $6.40 \mathrm{e}$ & $13.91 \mathrm{~g}$ & $57.7 \mathrm{e}$ & $2.19 \mathrm{~d}$ & $71.1 \mathrm{a}$ \\
\hline TM-127 & $8.35 \mathrm{c}$ & $25.87 \mathrm{c}$ & $93.8 \mathrm{~b}$ & $3.40 \mathrm{ab}$ & $64.4 \mathrm{ab}$ \\
\hline TM-128 & $11.2 \mathrm{a}$ & $38.93 \mathrm{a}$ & $102.5 \mathrm{a}$ & $3.23 \mathrm{bc}$ & $49.0 \mathrm{~cd}$ \\
\hline TM-131 & $9.37 \mathrm{~b}$ & $30.51 \mathrm{~b}$ & $87.9 \mathrm{bc}$ & $2.87 \mathrm{c}$ & $52.9 \mathrm{c}$ \\
\hline TM-132 & $4.31 \mathrm{f}$ & $16.81 \mathrm{f}$ & $41.0 \mathrm{f}$ & $1.21 \mathrm{f}$ & $44.5 \mathrm{~d}$ \\
\hline TM-133 & $8.82 \mathrm{bc}$ & $32.32 \mathrm{~b}$ & $107.3 \mathrm{a}$ & $3.75 \mathrm{a}$ & $60.1 \mathrm{~b}$ \\
\hline TM-134 & $7.30 \mathrm{~d}$ & $27.77 \mathrm{c}$ & $71.5 \mathrm{~d}$ & $2.19 \mathrm{~d}$ & $47.3 \mathrm{~cd}$ \\
\hline TM-160 & $4.49 \mathrm{f}$ & $18.62 \mathrm{ef}$ & $54.2 \mathrm{e}$ & $1.78 \mathrm{de}$ & $53.4 \mathrm{c}$ \\
\hline$L S D(0.05)$ & 0.72 & 2.40 & 6.71 & 0.39 & 6.27 \\
\hline
\end{tabular}

In a column figures having same letter ( $\mathrm{s}$ ) do not differ significantly at $\mathrm{P} \leq 0.05$ 
The mutant TM-128 showed higher TDM at both growth stages (38.93 and $107.3 \mathrm{~g}$ at 40 and 60 DAT, respectively) whereas at $60 \mathrm{DAT}$, TM-133 showed the highest TDM (107.3 g). On the contrary, Binatomato-4 and TM-132 produced lower TDM possibly for production fewer leaves plant ${ }^{-1}$ (Table 01). Increased TDM in TM-133 and TM-128 was possibly due to greater leaf number (Table 01). Similarly Mohanty (2002) reported TDM increases in high yielding genotypes compared to low yielding ones. TM-133 showed the highest AGR (3.75 g plant $^{-1}$ day $^{-1}$ ) followed by TM-127 (3.40 g plant${ }^{1}$ day $^{-1}$ ). The higher AGR in TM-133 and TM-127 might be due to production of higher LA (Table 01) and TDM (Table 02). On the other hand, TM-132 showed the lowest AGR (1.21 $\mathrm{g} \mathrm{plant}^{-1}$ day $\left.^{-1}\right)$ due to production of lower LA plant ${ }^{-1}$ (Table 01). Spatial distribution of the tomato plants was not developed to the level for intra competition. Thus, increased in LA content increased in TDM (Table 02) consequently AGR (Table 02) similar results observed by Andriolo et al. (1998). The relative growth rate (RGR) showed significant difference among the tomato genotypes studied (Table 02). The highest RGR was observed in Binatomato-4 and TM-113 (71.1 $\left.\mathrm{mg} \mathrm{g}^{-1} \mathrm{~d}^{-1}\right)$. These two genotypes was not high yielder (Table 05). In contrast, the lowest RGR was recorded in TM-132 (44.5 $\left.\mathrm{mg} \mathrm{g}^{-1} \mathrm{~d}^{-1}\right)$ that was also a low yielder. These results indicate that fruit yield had no relation with RGR in tomato. On the other hand Lee et al. (2002) reported that fruit yield had position correlation with RGR.

\section{Biochemical characters}

The highest chlorophyll content in leaf was recorded in TM-134 (2.75 mg g-1 fw) and the lowest chlorophyll content was observed in Binatomato-5 and TM-131 (2.36 mg g-1 fw). Dutta et al. (1995) reported that fruit yield was positively correlated with chlorophyll content in leaf. In the present investigation, the mutant TM-131 was high yielder with lower chlorophyll which indicates chlorophyll content in leaves is not obligatory for getting higher fruit yield in tomato. Nitrate reductase (NR) activity in the leaf at 60 DAT (reproductive stage) varied significantly among the studied mutants/variety (Table 03). The higher NR activity was recorded in Binatomato-5, TM-113, TM-128 and TM-133 with being the highest in TM-133 $\left(8.11 \mu \mathrm{mol} \mathrm{g}^{-1} \mathrm{fw}\right)$. In contrast, the lower NR activity was recorded in TM-132 (5.41 $\mu$ mol g-1fw) followed by TM-160 (5.63 $\mu$ mol g-1 fw). Dutta (2001) reported that NR activity in the leaves had significant positive correlation with fruit yield in tomato. Significant variation on total sugar content in leaf of tomato mutants and varieties was observed (Table 03), where high yielding genotypes, in general, showed higher total sugar in leaves than low yielding ones (Table 05). The highest total sugar was recorded in TM-133 (82.5 $\mathrm{mg} \mathrm{g}^{-1} \mathrm{fw}$ ) and the lowest was recorded in TM-132 (66.3 $\left.\mathrm{mg} \mathrm{g}^{-1} \mathrm{fw}\right)$ which was consistent with result of BINA (2008).

Table 03. Variation in biochemical characters of tomato mutants grown in winter.

\begin{tabular}{lllll}
\hline $\begin{array}{l}\text { Mutants/ } \\
\text { varieties }\end{array}$ & $\begin{array}{l}\text { Chlorophyll } \\
(\mathrm{mg} / \mathrm{gfw}) \dagger\end{array}$ & $\begin{array}{l}\text { Nitrate reductase } \\
(\mu \mathrm{mol} \text { NO2- } / \mathrm{gfw}) \dagger\end{array}$ & $\begin{array}{l}\text { Total sugar } \\
(\mathrm{mg} / \mathrm{gfw}) \dagger\end{array}$ & $\begin{array}{l}\text { Vit-C in ripen tomato } \\
(\mathrm{mg} / 100 \mathrm{gfw})\end{array}$ \\
\hline Binatomato-4 & $2.65 \mathrm{ab}$ & $6.40 \mathrm{c}$ & $72.4 \mathrm{cde}$ & $20.6 \mathrm{a}$ \\
Binatomato-5 & $2.36 \mathrm{~b}$ & $7.88 \mathrm{a}$ & $75.6 \mathrm{a}-\mathrm{d}$ & $19.1 \mathrm{abc}$ \\
$\mathrm{TM}-113$ & $2.68 \mathrm{ab}$ & $7.86 \mathrm{a}$ & $80.2 \mathrm{ab}$ & $18.4 \mathrm{a}-\mathrm{d}$ \\
$\mathrm{TM}-127$ & $2.60 \mathrm{ab}$ & $7.22 \mathrm{~b}$ & $74.3 \mathrm{bcd}$ & $14.8 \mathrm{e}$ \\
$\mathrm{TM}-128$ & $2.46 \mathrm{ab}$ & $7.90 \mathrm{a}$ & $80.6 \mathrm{ab}$ & $16.4 \mathrm{cde}$ \\
$\mathrm{TM}-131$ & $2.36 \mathrm{~b}$ & $6.30 \mathrm{c}$ & $78.3 \mathrm{abc}$ & $15.5 \mathrm{de}$ \\
$\mathrm{TM}-132$ & $2.64 \mathrm{ab}$ & $5.41 \mathrm{~d}$ & $66.3 \mathrm{e}$ & $20.1 \mathrm{ab}$ \\
$\mathrm{TM}-133$ & $2.42 \mathrm{ab}$ & $8.11 \mathrm{a}$ & $82.5 \mathrm{a}$ & $17.3 \mathrm{~b}-\mathrm{e}$ \\
$\mathrm{TM}-134$ & $2.75 \mathrm{a}$ & $7.62 \mathrm{ab}$ & $73.2 \mathrm{~cd}$ & $20.0 \mathrm{ab}$ \\
$\mathrm{TM}-160$ & $2.64 \mathrm{ab}$ & $5.63 \mathrm{~d}$ & $68.7 \mathrm{de}$ & $21.0 \mathrm{a}$ \\
\hline$L S D(0.05)$ & 0.33 & 0.52 & 6.31 & 2.75 \\
\hline$C V(\%)$ & 7.38 & 4.28 & 4.89 & 8.73 \\
\hline
\end{tabular}

In a column figures having same letter (s) do not differ significantly at $\mathrm{P} \leq 0.05$; $\dagger$ : Data was collected at 60 DAT i.e. flowering and fruiting stage

Significant variation in Vitamin-C (Vit-C) content in fruit due to genotypes was also observed in tomato (Table 03). The highest Vit-C was observed in TM-160 (21.0 mg/100 gfw) which was non-significant different with Binatomato-4 (20.6 mg/100 gfw), TM-132 (20.1 mg/100 gfw) and TM-134 (20.0 $\mathrm{mg} / 100 \mathrm{gfw}$ ). The lowest Vit-C was recorded in TM-127 (14.8 mg/100 gfw) followed by TM-131 (15.5 
$\mathrm{mg} / 100 \mathrm{gfw})$ and TM-128 (16.4 mg/100 gfw). Results revealed that large size fruit had lesser amount of Vit-C than smaller size ones in tomato (BINA, 2003).

\section{Reproductive characters}

The genotypic variation on the number of effective and non-effective flower clusters plant ${ }^{-1}$, flower production plant ${ }^{-1}$, reproductive efficiency (RE) were significant (Table 04). TM-133 produced the highest number of effective flower clusters plant ${ }^{-1}$ (19.7). The mutant TM-113 produced the lowest number of effective flower cluster plant ${ }^{-1}$ (10.1). Results revealed that high yield genotypes produced greater number of effective flower cluster than low yielding ones While fruit yield had no relation with non-effective flower cluster plant ${ }^{-1}$ (BINA, 2007). In the same way TM-128, the high yielding mutant, produced the highest number of non-effective flower clusters plant ${ }^{-1}(10.0)$ whereas Binatomato-5, the low yielding variety, produced higher number of non-effective flower clusters plant ${ }^{-1}$ (9.89). Number of flower production per plant had no relation with fruit yield. Binatomato-5, the low yielding variety produced the highest number of flowers plant $^{-1}$ (81.7) while TM-128, the high yielding mutant also showed higher flowers plant ${ }^{-1}$ (80.2). In contrast, the lowest number of flowers plant was recorded in TM-113 (52.3). This type of genotypic variation in flower number was also observed by BINA (2008). Reproductive efficiency did not show any regular pattern with fruit yield like plant height or branches. The higher RE was recorded in Binatomato-4, TM-133, TM-134 and TM-160 with being the highest in TM-160 (78.9\%). The lowest RE was recorded in TM-132 (51.9\%). Genotypic variation in RE was also observed by BINA (2007) in tomato.

\section{Table 04. Variation in reproductive characters of tomato mutants and varieties}

\begin{tabular}{lllll}
\hline $\begin{array}{l}\text { Mutants/ } \\
\text { varieties }\end{array}$ & $\begin{array}{l}\text { Effective flower } \\
\text { clusters/plant (no.) }\end{array}$ & $\begin{array}{l}\text { Non- effective flower } \\
\text { clusters/plant (no.) }\end{array}$ & $\begin{array}{l}\text { Flowers/ } \\
\text { plant (no.) }\end{array}$ & $\begin{array}{l}\text { Reproductive } \\
\text { efficiency (\%) }\end{array}$ \\
\hline Binatomato-4 & $14.9 \mathrm{~cd}$ & $9.11 \mathrm{~cd}$ & $69.2 \mathrm{~cd}$ & $73.0 \mathrm{a}$ \\
Binatomato-5 & $18.4 \mathrm{~b}$ & $9.89 \mathrm{ab}$ & $81.7 \mathrm{a}$ & $52.8 \mathrm{~cd}$ \\
TM-113 & $10.1 \mathrm{~g}$ & $6.22 \mathrm{fg}$ & $52.3 \mathrm{f}$ & $56.5 \mathrm{~cd}$ \\
TM-127 & $13.5 \mathrm{ef}$ & $9.33 \mathrm{bc}$ & $62.0 \mathrm{e}$ & $66.4 \mathrm{~b}$ \\
TM-128 & $16.0 \mathrm{c}$ & $10.0 \mathrm{a}$ & $80.2 \mathrm{a}$ & $58.7 \mathrm{c}$ \\
TM-131 & $14.6 \mathrm{de}$ & $6.66 \mathrm{f}$ & $67.7 \mathrm{~cd}$ & $54.9 \mathrm{~cd}$ \\
TM-132 & $13.2 \mathrm{f}$ & $9.11 \mathrm{~cd}$ & $74.6 \mathrm{~b}$ & $51.9 \mathrm{~d}$ \\
TM-133 & $19.7 \mathrm{a}$ & $7.33 \mathrm{e}$ & $70.9 \mathrm{bc}$ & $78.2 \mathrm{a}$ \\
TM-134 & $18.4 \mathrm{~b}$ & $8.62 \mathrm{~d}$ & $65.5 \mathrm{de}$ & $75.7 \mathrm{a}$ \\
TM-160 & $13.8 \mathrm{def}$ & $5.78 \mathrm{~g}$ & $43.1 \mathrm{~g}$ & $78.9 \mathrm{a}$ \\
\hline$L S D(0.05)$ & 1.12 & 0.62 & 4.81 & 5.67 \\
\hline
\end{tabular}

In a column figures having same letter ( $\mathrm{s}$ ) do not differ significantly at $\mathrm{P} \leq 0.05$

\section{Yield contributing characters}

The yield contributing characters i.e., number of fruits plants, single fruit weight and fruit yield among the studied mutants/varieties varied significantly (Table 05). The highest number of fruits plant ${ }^{-1}$ was recorded in TM-133 (58.1) followed by TM-131 (54.0). These two mutants also showed higher fruit yield. In contrast, TM-113 produced the lowest number of fruits plant ${ }^{-1}$ (19.5) but showed not the lowest fruit yield due to larger size fruits. This type of genotypic variation in fruit number also observed by Bhangu and Singh (1993).

TM-113 produced the highest single fruit weight $(75.7 \mathrm{~g})$ which was significantly different than the others. The lowest single fruit weight was found in Binatomato-5 (38.0 g). This result of variability in single fruit weight agreed with report of BINA (2007). In case of fruit yield the mutant TM-133 showed the highest fruit yield plant ${ }^{-1}(2.86 \mathrm{~kg})$ followed by TM-128 (2.67) and TM-131 (2.54 kg) with same statistical rank (Table 05). The yield was higher in these three mutants because of production of higher number fruits plant ${ }^{-1}$. In contrast, TM-132 showed the lowest fruit yield (1.35 kg) due to the production of fewer fruits plant ${ }^{-1}$ as well as smaller fruit size. Most of the researchers reported that fruit yield in tomato mostly depend on fruit number and fruit size (Islam et al., 1996; Sandri et al., 2003; Singh and Raj, 2004; Kabir, 2004; Karim, 2005; Sharma et al., 2006; Hidayatullah et al., 2008). 
The fruit yield hectare ${ }^{-1}$ was converted from the value of fruit yield plot ${ }^{-1}$. So the yield performance of per unit area basis was appeared to be similar to that of per plant yield.

Table 05. Genotypic effect on the yield and yield attributes of studied tomato mutants and varieties

\begin{tabular}{lllll}
\hline $\begin{array}{l}\text { Mutants/ } \\
\text { varieties }\end{array}$ & Fruits/plant (no.) & Single fruit weight (g) & Fruit weight/plant (kg) & $\begin{array}{l}\text { Fruit yield } \\
\text { (t/ha) }\end{array}$ \\
\hline Binatomato-4 & $44.0 \mathrm{~d}$ & $43.6 \mathrm{e}$ & $1.92 \mathrm{~d}$ & $67.2 \mathrm{e}$ \\
Binatomato-5 & $48.3 \mathrm{~cd}$ & $38.0 \mathrm{f}$ & $1.84 \mathrm{~d}$ & $64.4 \mathrm{e}$ \\
TM-113 & $19.5 \mathrm{~g}$ & $75.7 \mathrm{a}$ & $1.48 \mathrm{e}$ & $51.8 \mathrm{f}$ \\
TM-127 & $47.2 \mathrm{~cd}$ & $48.3 \mathrm{~cd}$ & $2.28 \mathrm{c}$ & $79.8 \mathrm{~d}$ \\
TM-128 & $49.8 \mathrm{bc}$ & $60.4 \mathrm{~b}$ & $2.67 \mathrm{ab}$ & $93.4 \mathrm{~b}$ \\
TM-131 & $54.0 \mathrm{ab}$ & $53.0 \mathrm{c}$ & $2.54 \mathrm{ab}$ & $88.9 \mathrm{bc}$ \\
TM-132 & $28.9 \mathrm{f}$ & $46.7 \mathrm{de}$ & $1.35 \mathrm{e}$ & $47.3 \mathrm{f}$ \\
TM-133 & $58.1 \mathrm{a}$ & $49.2 \mathrm{~cd}$ & $2.86 \mathrm{a}$ & $100.1 \mathrm{a}$ \\
TM-134 & $51.2 \mathrm{bc}$ & $48.9 \mathrm{~cd}$ & $2.40 \mathrm{bc}$ & $84.0 \mathrm{~cd}$ \\
TM-160 & $35.4 \mathrm{e}$ & $51.4 \mathrm{~cd}$ & $1.82 \mathrm{~d}$ & $63.7 \mathrm{e}$ \\
\hline$L S D(0.05)$ & 5.15 & 5.33 & 0.34 & 5.69 \\
\hline
\end{tabular}

In a column figures having same letter ( $\mathrm{s}$ ) do not differ significantly at $\mathrm{P} \leq 0.05$;

\section{Association of characters}

Phenotypic correlation coefficients among different quantitative characters are presented in the Table 06 . Fruit yield plant ${ }^{-1}$ was positively and significantly correlated with leaf area $\left(r=0.62^{* *}\right)$, total dry mass $\left(\mathrm{r}=0.78^{* *}\right)$, nitrate reductase $\left(\mathrm{r}=0.42^{*}\right)$, total sugar $\left(\mathrm{r}=0.52^{* *}\right)$, absolute growth rate $\left(\mathrm{r}=0.69^{* *}\right)$, the number of flower cluster $\left(\mathrm{r}=0.58^{* *}\right)$ and fruits plant $^{-1}\left(\mathrm{r}=0.81^{* *}\right)$ but showed negative association with chlorophyll $(\mathrm{r}=-0.34)$ and relative growth rate $(\mathrm{r}=-0.15)$. Therefore, fruit yield could be improved by selecting tomato genotype(s) having increased leaf area, TDM and increased number of flower cluster per plant. However, number of fruits plant ${ }^{-1}$ was highly significant and positively correlated with TDM plant ${ }^{-1}\left(\mathrm{r}=0.70^{* *}\right)$, AGR $\left(\mathrm{r}=0.63^{* *}\right)$ and number of flower cluster plant ${ }^{-1}\left(\mathrm{r}=0.80^{* *}\right)$ but significantly negative associated with fruit size $\left(\mathrm{r}=-0.46^{* *}\right)$ i.e. fruit size and number is negative associated with each other. Interestingly, chlorophyll and RGR had no significant positive association in most of the plant characters indicating chlorophyll content in leaves and RGR should not consideration for tomato improvement but nitrate reductase and AGR should be considered for tomato yield improvement. The above results are supported by many scientists in tomato (Heuvelink, 1999; Lee et al., 2002; Sandri et al., 2003; Singh and Raj, 2004; Sharma et al., 2006; Hidayatullah et al., 2008).

\section{Conclusion}

Growth and development, biochemical parameters, yield contributing characters and yield of the studied tomato mutants varied significantly. Among them the mutants TM-128, TM-131 and TM-133 were superior to other mutants/varieties. The mutant TM-133 appears to be the best one and may be treated as superior one to release as variety. However, further studies are needed to confirm their performance in the other locations.

\section{References}

[1]. Ahmed, K. U. (2008). Cultivation method of BARI released varieties. Bangladesh Agricultural Research Institute, Gazipur-1701, Bangladesh. pp. 85-96.

[2]. Andriolo, J. L. A., Streck, N. A., Buriol, G. A, Lilke, L. \& Duarte, T. S. (1998). Growth, development and dry matter distribution of tomato crop as affected by environment. Journal of Horticultural Science and Biotechnology, 73(1), 125-130.

http://dx.doi.org/10.1080/14620316.1998.11510954 
[3]. AOAC (Association of Official Analytical Chemists). (1980). Official Methods of Analysis. 13th Ed, Washington D.C.

https://archive.org/stream/gov.law.aoac.methods.1980/aoac.methods.1980_djvu.txt

[4]. Asati, B. S., Rai, N. \& Singh, A. K. (2008). Genetic parameters study for yield and quality traits in tomato. Asian Journal of Horticulture, 3(2), 222-225.

[5]. Ashrafuzzaman, M., Haque, M. A., Razi Ismail, M., Islam, M. T. \& Shahidullah, S. M. (2010). Genotypic and Seasonal Variation in Plant Development and Yield Attributes in Tomato (Lycopersicon esculentum Mill.) Cultivars. International Journal of Botany, 6, 41-46 http://dx.doi.org/10.3923/ijb.2010.41.46

[6]. BBS. (2009). Hand book of Agricultural Statistics, December, 2009. Bangladesh Bureau of Statistics. Ministry of Planning, Govt. People's Repub. Bangladesh. p. 14.

[7]. Begum, S. (2005). Studies on the development of summer tomato through mutation breeding. Ph.D Thesis, Dept. Bot., Dhaka Univ., Dhaka.

[8]. Bhangu, J. S. \& Singh, S. (1993). Comparative performance of tomato cultivars under rainfed conditions of Kandi area (Panjab). J. Panjab Hortic., 33, 123-126.

[9]. BINA. (2003). Annual Report for 2002-2003 of Bangladesh Institute of Nuclear Agriculture. BINA, P. O. Box-4, Mymensingh, Bangladesh. p. 48.

[10]. BINA. (2007). Annual Report for 2006-07 of Bangladesh Institute of Nuclear Agriculture. BINA, P. O. Box-4, Mymensingh, Bangladesh. p. 58.

[11]. BINA. (2008). Annual Report for 2007-08 of Bangladesh Institute of Nuclear Agriculture. BINA, P. O. Box-4, Mymensingh, Bangladesh. p. 61.

[12]. Bose, T. K. \& Som, M. G. (1990). Vegetable Crops in India. NayaProkash, 206 BidhanSarani, Calcutta, India. p. 249.

[13]. Dubois, M., Gilles, K. A., Hamilton, J. K., Robers, P. A. \& Smith, F. (1956). Colorimetric method for determination of sugars and related substances. Anaytical Chemistry, 28(3), 350-356. http://dx.doi.org/10.1021/ac60111a017

[14]. Dutta, R. K. (2001). Assessment of the advanced mutant lines/varieties of BINA with emphasis on physiological criteria. Report on ARMP Project \# 112, BARC, Farmgate, Dhaka 1215. pp. 5253.

[15]. Dutta, R. K. (2004). Role of biochemical parameters to tomato yield. J. Agric. Sci., 24, 23-28.

[16]. Dutta, R. K., Islam, M. S., Baset Mia, M. A., Majid, M. A. \& Lahiri, B. P. (1995). Comparative assessment of tomato varieties/advanced lines in relation to growth, yield and quality. Bangladesh Journal of Nuclear Agriculture, 11, 27-35.

[17]. FAO. (2007). Production Year Book of 2006. No. 67. Food and Agriculture Organization (FAO), Rome, Italy. p. 54.

[18]. Heuvelink, E. (1999). Evaluation of dynamic simulation model for tomato crop growth and development. Annals of Botany, 83 (4), 413-422. http://dx.doi.org/10.1006/anbo.1998.0832

[19]. Hidayatullah, M., Jatoi, S. A., Ghafoor, A. \& Mahmood, T. (2008). Path coefficient analysis of yield component in tomato. Pakistan Journal of Botany, 40 (2), 627-635.

[20]. Hossain, M. M., Khalequzzaman, K. M., Amzad Hossain, M., Mollah, M. R. A. \& Siddique, M. A. (2004). Influence of Planting Time on the Extension of Picking Period of Four Tomato Varieties. Journal of Biological Sciences, 4(5), 616-619. http://dx.doi.org/10.3923/jbs.2004.616.619

[21]. Hunt, R. (1978). Plant growth analysis. Studies in biology No. 96 Edward Arnold Ltd., London. p. 67.

[22]. Islam, P., Prakash, S. \& Singh, A. K. (1996). Variability studies in tomato (Lycopersicon esculentum Mill.) under sub-humid conditions of Himachal Prodesh. South Indian Horticulture, 44(5\&6), 132-134.

[23]. Kabir, M. S. A. (2004). Morpho physiological evaluation of elite genotypes of tomato in early summer season. M. S Thesis, Dept. Crop Bot., Bangladesh Agric. Univ., Mymensingh.

[24]. Karim, M. R. (2005). Study of growth and yield performance of late transplanted summer tomato genotypes. M. S Thesis, Dept. Crop Bot., Bangladesh Agric. Univ., Mymensingh.

[25]. Lee, J. H., Heuvelink, E. \& Challa, H. (2002). Effects of planting date and plant density on crop growth of tomato. Journal of Horticultural Science and Biotechnology, 77(2), 238-247.

[26]. Mohanty, B. K. (2002). Studies on variability, heritability, interrelationship and path analysis in tomato. Annals of Agricultural Research, 23(1), 65-69.

[27]. Prashanth, S. J., Jaiprakkashnarayan, R. P., Mulge, R. \& Madalageri, M. B. (2008). Correlation and path analysis in tomato. Asian Journal of Horticulture, 3(2), 403-408. 
[28]. Russell, D. F. (1986). MSTAT-C computer package programme. Crop and Soil Sci. Dept., Michigan State Univ., USA.

[29]. Sandri, M. A., Andriolo, T. L., Witter, M. \& Ross, T. D. (2003). Effect of shading on tomato plants grown under greenhouse. Horticultura Brasileira, 21(4), 412-416. http://dx.doi.org/10.1590/S0102-05362003000400013

[30]. Sharma, J. P., Sanjeev, K., Singh, A. K. \& Anil, B. (2006). Variability and inter relationship studies in tomato. SKUAST Journal of Research, 5, 22-27.

[31]. Singh, A. K. \& Raj, N. (2004). Variability studies in tomato under cold arid condition of Ladakh. Horticulture Journal, 17(1), 67-72.

[32]. Singh, S. K., Singh, I. P., Singh, B. B. \& Singh, O. (2009). Correlation and path coefficient studies for yield and its components in mungbean (Vigna radiate L.). Legume Research, 32(3), 316-318 http://www.arccjournals.com/uploads/articles/lr323004.pdf

[33]. Stewart, G, R. \& Orebamjo, T. O. (1979). Some unusual characteristics of nitrate reduction in Erythrina senegalensis DC. New Phytologist, 83(2), 311-319. http://dx.doi.org/10.1111/j.14698137.1979.tb07456.x

[34]. Yoshida, S., Forno, D. A., Cock, J. A. \& Gomes, K. A. (1976). Laboratory manual for physiological studies of rice. 3rd ed., IRRI, Los Banos, Philippines.

\section{How to cite this article?}

\section{APA (American Psychological Association)}

Ghosh, S., Khan, M. H., Saha, K. C., Azam, M. G. \& Pramanik, M. H. R. (2016). Performance of eight tomato mutants in winter season. Journal of Bioscience and Agriculture Research, 09(01), 782-791.

\section{MLA (Modern Language Association)}

Ghosh, S., Khan, M. H., Saha, K. C., Azam, M. G. \& Pramanik, M. H. R. "Performance of eight tomato mutants in winter season". Journal of Bioscience and Agriculture Research, 09.01 (2016), 782-791.

\section{Chicago/Turabian}

Ghosh, S., Khan, M. H., Saha, K. C., Azam, M. G. \& Pramanik, M. H. R. "Performance of eight tomato mutants in winter season". Journal of Bioscience and Agriculture Research, 09, no. 01 (2016), 782-791. 
Table 06. Simple correlation coefficient among different characters of tomato mutants/variety ${ }^{\dagger}$

\begin{tabular}{|c|c|c|c|c|c|c|c|c|c|c|c|c|}
\hline Characters & 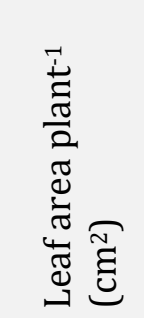 & 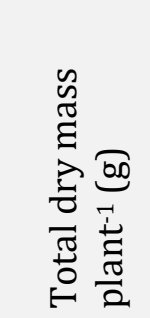 & 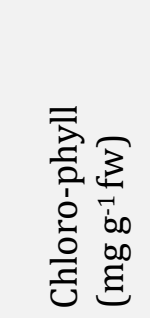 & 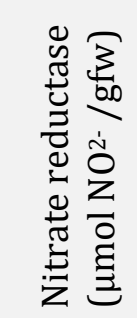 & 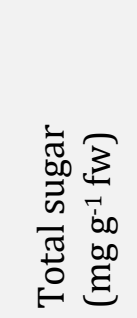 & 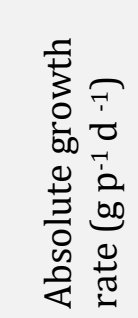 & 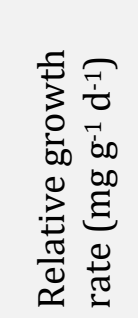 & 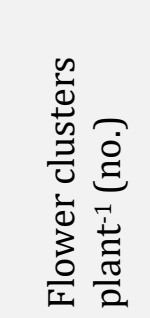 & 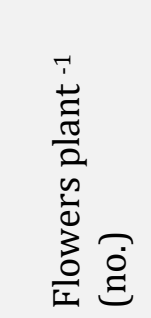 & 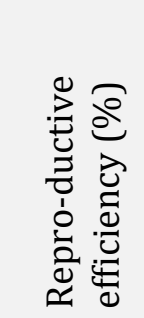 & 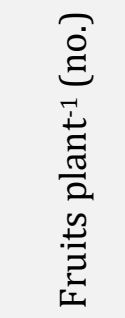 & 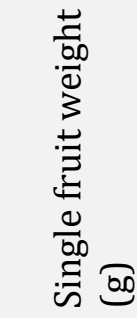 \\
\hline Fruit yield & $0.62^{* *}$ & $0.78^{* *}$ & -0.34 & $0.42^{*}$ & $0.52^{* *}$ & $0.69 * *$ & -0.15 & $0.58 * *$ & 0.26 & 0.30 & $0.81^{* *}$ & 0.09 \\
\hline Fruit number & $0.44^{*}$ & $0.70^{* *}$ & $-0.45^{*}$ & $0.45^{*}$ & 0.34 & $0.63^{* *}$ & -0.18 & $0.80 * *$ & $0.45^{*}$ & 0.32 & --- & $-0.46^{* *}$ \\
\hline Single fruit weight & $0.52^{* *}$ & 0.003 & 0.12 & 0.26 & $0.38^{*}$ & 0.01 & 0.07 & $-0.55^{* *}$ & $-0.42^{*}$ & -0.15 & $-0.46^{*}$ & --- \\
\hline Plant height & $0.71^{* *}$ & $0.57^{* *}$ & -0.22 & $0.84^{* *}$ & $0.67^{* *}$ & $0.62^{* *}$ & 0.30 & 0.06 & 0.21 & -0.30 & 0.04 & $0.54^{* *}$ \\
\hline Branch number & $0.44^{*}$ & $0.47^{* *}$ & -0.23 & $0.77^{* *}$ & $0.51^{* *}$ & $0.52^{* *}$ & $0.36^{*}$ & 0.25 & $0.53^{* *}$ & $-0.41^{*}$ & 0.08 & 0.14 \\
\hline Leaf area & --- & $0.80^{* *}$ & -0.31 & $0.60 * *$ & $0.72^{* *}$ & $0.74^{* *}$ & -0.09 & 0.08 & 0.16 & -0.15 & $0.44^{*}$ & $0.52^{* *}$ \\
\hline Total dry mass & --- & --- & $-0.51^{* *}$ & $0.64^{* *}$ & $0.61^{* *}$ & $0.95^{* *}$ & -0.08 & $0.51^{* *}$ & $0.35^{*}$ & 0.002 & $0.70^{* *}$ & 0.003 \\
\hline Chlorophyll & --- & --- & --- & -0.22 & -0.25 & $-0.42^{*}$ & -0.04 & -0.28 & -0.31 & 0.23 & $-0.45^{*}$ & 0.12 \\
\hline Nitrate reductase & --- & --- & --- & --- & $0.68^{* *}$ & $0.66^{* *}$ & 0.31 & $0.42^{*}$ & 0.29 & 0.05 & $0.45^{*}$ & 0.26 \\
\hline Total sugar & --- & --- & --- & --- & --- & $0.64^{* *}$ & 0.29 & 0.22 & 0.16 & -0.10 & 0.34 & $0.38^{*}$ \\
\hline Absolute growth rate & & & & & & --- & 0.13 & $0.44^{*}$ & 0.30 & 0.004 & $0.63^{* *}$ & 0.008 \\
\hline Rrelative growth rate & & & & & & & --- & -0.19 & -0.14 & 0.03 & -0.18 & 0.07 \\
\hline Flower cluster number & & & & & & & & --- & $0.54^{* *}$ & 0.34 & $0.80 * *$ & $-0.55^{* *}$ \\
\hline Flower number & & & & & & & & & --- & $-0.42^{*}$ & $0.45^{*}$ & $-0.42^{*}$ \\
\hline
\end{tabular}

Flower number

${ }^{*},{ }^{*}$ significant at 5 and $1 \%$ level of probability; $\dagger$ : Fruit yield and other yield attributes had no significant positive correlation with plant height and branch number. 